\title{
Pemberdayaan Masyarakat melalui Edukasi Cara Pembuatan Pangan Olahan yang Baik, Bahan Tambahan Pangan, dan Kemasan Pangan untuk Penguatan Jaminan Keamanan pada Pelaku UMKM Bidang Makanan di Balikpapan
}

\author{
Increasing Community Empowerment through Education of Good Processed Food Processing, \\ Use of Food Additives, and Selection of Save Food Packaging to Improve Understanding of \\ Small and Micro Food Enterprises in Balikpapan
}

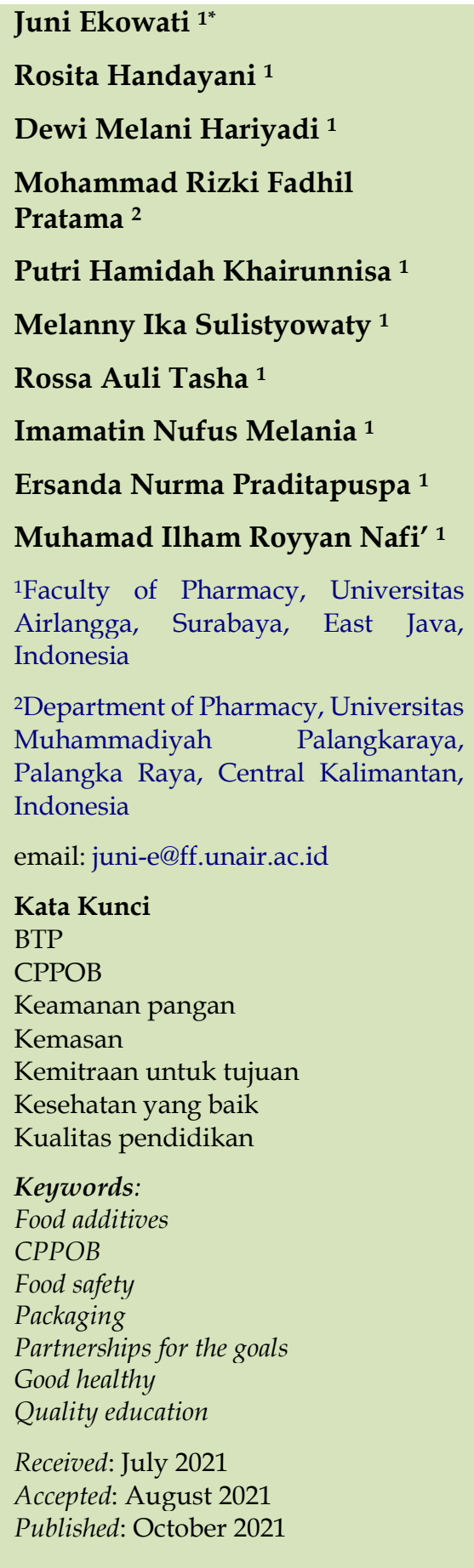

\begin{abstract}
Abstrak
Keamanan pangan adalah isu kompleks melibatkan banyak stakeholder dalam penanganannya. Isu keamanan pangan berkembang luas dan menjadi perhatian di masyarakat karena berhubungan dengan kualitas kesehatan dan kesejahteraan yang baik bagi konsumen. Kegiatan pengabdian masyarakat yang dilakukan dengan edukasi yang berkualitas berfokus pada isu mengenai Cara Pembuatan Pangan Olahan yang Baik (CPPOB), penggunaan Bahan Tambahan Pangan (BTP) yang aman, serta pertimbangan pemilihan kemasan yang menjamin keamanan pangan. Edukasi dilakukan untuk meningkatkan pemahaman para pelaku UMKM terhadap regulasi yang berlaku. Edukasi dilakukan secara daring menggunakan platform zoom meeting. Penyampaian materi dilakukan satu arah melalui ceramah dan tanya jawab. Peningkatan pemahaman peserta diukur dengan melihat sebaran nilai, nilai rata-rata, dan uji statistik pretest dan posttest. Efektivitas dan kualitas proses edukasi diukur menggunakan kuesioner evaluasi dengan indikator yang sudah ditentukan. Edukasi dilakukan terkait cara pengolahan produk pangan yang baik, penggunaan bahan pangan, dan pemilihan kemasan pangan yang dilakukan oleh tim pengabdian masyarakat Departemen Ilmu Kefarmasian Fakultas Farmasi Universitas Airlangga kepada para pelaku UMKM di Balikpapan terbukti meningkatkan pemahaman para pelaku usaha dan mampu memenuhi target indikator evaluasi kegiatan yang telah ditentukan.
\end{abstract}

\begin{abstract}
Food safety is a complex issue that involves stakeholders in its handling. The point of food safety is growing widely and is becoming a concern in the community because it is related to the quality of consumers' good health and well being. The community service activities based on quality education focused on Good Processed Food Manufacturing Practices (CPPOB), safe use of Food Additives (BTP), and consideration of packaging selection that ensures food safety. Education is carried out to increase the understanding of SMEs actors regarding regulations of $\mathrm{CPPOB}$, the use of BTP, and provisions on Food Packaging. The education process is carried out online using the Zoom Meeting platform. Learning activity is carried out in one direction through lectures and questions and answers sessions. The increase in participants' understanding was measured by comparing the distribution of average scores, pretest, and post-test statistical tests. The effectiveness and quality of the educational process were measured using an evaluation questionnaire with predetermined indicators. The education carried out related to CPPOB, the use of BTP, and the selection of food packaging performed by the community service team of the Department of Pharmaceutical Sciences, Faculty of Pharmacy, Universitas Airlangga to SMEs in Balikpapan has proven to increase the understanding of business actors. It can fulfill their needs and target activity evaluation indicators that have been determined.
\end{abstract}




\section{PENDAHULUAN}

Di tengah kondisi pandemi COVID-19 yang disertai dengan banyaknya bermunculan usaha kecil dan mikro di bidang makanan sebagai usaha meningkatkan pendapatan masyarakat, penjaminan keamanan pangan menjadi masalah krusial yang layak mendapat perhatian. Adanya berbagai inovasi dan perkembangan teknologi telah ditemukan untuk membuat proses produksi menjadi lebih efisien dari segi waktu, tempat, dan biaya. Industri makanan menemukan cara baru untuk memikat konsumen dengan biaya seminimal mungkin dengan tujuan mendapatkan keuntungan ekonomi. Biaya produksi menjadi salah satu pertimbangan penting bagi seseorang dalam berusaha, sehingga berbagai macam penyesuaian dilakukan untuk meminimalkan aspek ini dalam proses produksi. Beberapa bentuk penyesuaian biaya ini tersebut, terkadang mengesampingkan isu pokok mengenai mutu dan keamanan produk sehingga dapat membahayakan konsumen. Badan Pengawas Obat dan Makanan (BPOM) menemukan berbagai jenis pelanggaran pada saat melakukan inspeksi produksi produk pangan antara lain pemenuhan aspek Cara Pembuatan Pangan Olahan yang Baik (CPPOB) yang belum maksimal, adanya produk rusak, kemasan rusak atau penyok, kedaluwarsa, dan pangan mengandung Bahan Berbahaya/Bahan Tambahan Pangan mengandung Bahan Berbahaya (Badan Pengawas Obat dan Makanan Republik Indonesia, 2019a). Berdasarkan hal tersebut, kegiatan pengabdian masyarakat yang dilakukan adalah edukasi mengenai pemenuhan aspek Cara Pembuatan Pangan Olahan yang Baik (CPPOB), penggunaan Bahan Tambahan Pangan (BTP) yang aman, serta pertimbangan pemilihan kemasan yang sesuai, dimana ketiga hal tersebut merupakan faktor penting dalam menjamin mutu dan keamanan pangan olahan.
Pemerintah melalui Kementerian Perindustrian telah menerbitkan Permenperin RI no 75/MIND/PER/7/2010 tentang Pedoman Cara Produksi Pangan Olahan yang Baik (Good Manufacturing Practices), atau selanjutnya disebut $\mathrm{CPPOB}$, untuk menghasilkan menghasilkan pangan olahan yang bermutu, aman untuk dikonsumsi, dan sesuai dengan tuntutan konsumen. Kondisi saat ini, hasil pemeriksaan industri rumah tangga pangan (IRT-P) oleh BPOM pada tahun 2019 menyebutkan bahwa 2.364 (73,48\%) IRT-P belum menerapkan CPPOB. Ketidaksesuaian CPPOB untuk IRTP antara lain adalah IRTP tidak memiliki dokumen produksi; karyawan di bagian produksi pangan tidak mengenakan pakaian kerja dan/atau mengenakan perhiasan; dokumen produksi tidak mutakhir, tidak akurat, tidak tertelusur; dan lantai, dinding, dan langitlangit, tidak terawat, kotor, berdebu dan atau berlendir (Badan Pengawas Obat dan Makanan Republik Indonesia, 2019a).

Pemerintah melalui BPOM juga telah telah menerbitkan Perka BPOM No 11 tahun 2019 tentang Bahan Tambahan Pangan, 2019. Peraturan tersebut meregulasi jenis BTP yang boleh digunakan, batas maksimal BTP yang digunakan, serta jumlah harian BTP yang aman dikonsumsi oleh tubuh (Acceptable Daily Intake). BTP yang paling sering digunakan pada industri rumah tangga (IRT) dan usaha mikro adalah pemanis, pengawet, dan pewarna, Penggunaan jenis BTP harus sesuai dengan jenis yang diizinkan serta dalam batas kadar yang diperbolehkan. Pewarna makanan buatan berlebihan dapat menyebabkan gejala gangguan attention-deficit/hyperactivity. Penggunaan pengawet nitrat dan nitrit berlebihan dapat mengganggu produksi hormon tiroid dan, dalam kondisi endogen tertentu, dapat mengakibatkan peningkatan produksi senyawa N-nitroso karsinogenik (Trasande et al., 2018). Penggunaan pemanis berlebih dapat meningkatkan 
risiko asam urat, hipertensi, dan diabetes (Curhan \& Forman, 2010; Daher et al., 2019). Penggunaan BTP melebihi kadar yang diperbolehkan dan diluar jenis yang diizinkan ini dapat mengancam kesehatan masyarakat, terutama terhadap kaum yang rentan yaitu anak-anak dan ibu hamil/menyusui. Data BPOM tahun 2019 menemukan masih banyak produk pangan olahan yang tidak memenuhi syarat batas BTP, dan penggunaan BTP yang dilarang seperti formalin, boraks, rhodamin B, dan metilen yellow menjadi penyebab tidak memenuhi syarat (TMS) terbesar dari sampel yang diuji berturut-turut sebesar 27,7\%; 33,4\%; 38,3\%; dan 0,6\% (Badan Pengawas Obat dan Makanan Republik Indonesia, 2019a).

Isu ketiga adalah isu mengenai pemilihan kemasan pangan. Isu ini penting diangkat karena kemasan merupakan faktor esensial yang mempengaruhi keamanan pangan dari kerusakan. Pemilihan kemasan yang sesuai juga harus mempertimbangkan faktor keamanan bahan kemasan dalam rangka meminimalkan terjadinya perpindahan (migrasi) senyawa berbahaya pada kemasan (Piringer \& Baner, 2008). Jika makanan rusak karena kemasan yang tidak sesuai, maka produk pangan dapat mengalami penurunan kualitas, termasuk rasa, tekstur, warna, dan sifat sensorik lainnya. Beberapa bahan pangan juga dapat menghasilkan pelepasan senyawa yang berbahaya misalnya bisfenol A dan ftalat. Pelepasan bisfenol A (BPA) 4 yang melebihi batas dapat memicu konversi sel menjadi adiposit, mengganggu fungsi sel pankreas secara in vivo, dan mempengaruhi transportasi glukosa di adiposit sehingga memicu atherosclerosis, obesitas, diabetes tipe 2 dan sindroma metabolik (Chaldakov et al., 2013; Perdana \& Jacobus, 2016). Sedangkan pelepasan senyawa ftalat dari kemasan akan memengaruhi ekspresi regulator utama metabolisme lipid dan karbohidrat dan berujung pada penyakit- penyakit gangguan metabolic (Alamri et al., 2021). Kualitas gizi juga akan terpengaruh selama proses kerusakan makanan.

Salah satu solusi yang dikembangkan saat ini adalah green packaging (kemasan hijau) yang dipercaya dapat meningkatkan keamanan pangan dan sebagai salah satu faktor pendukung keunggulan kompetitif. Dengan paradigma ini, kode daur ulang kemasan 3 (ftalat), 6 (stirena), dan 7 (bisfenol) mulai ditinggalkan di beberapa dunia.

Dengan analisis 3 isu tersebut, maka tim pengabdian masyarakat Departemen Ilmu Kefarmasian Fakultas Farmasi Universitas Airlangga (Gambar 1) melakukan edukasi kepada para pelaku usaha kecil dan mikro (UMKM dan IRT-P) terhadap penggunaan BTP dan aspek-aspek yang berlaku pada CРPOB, serta pertimbangan pemilihan kemasan. Kegiatan edukasi dilakukan secara daring kepada pelaku UMKM dengan melibatkan IAI Balikpapan sebagai mitra.

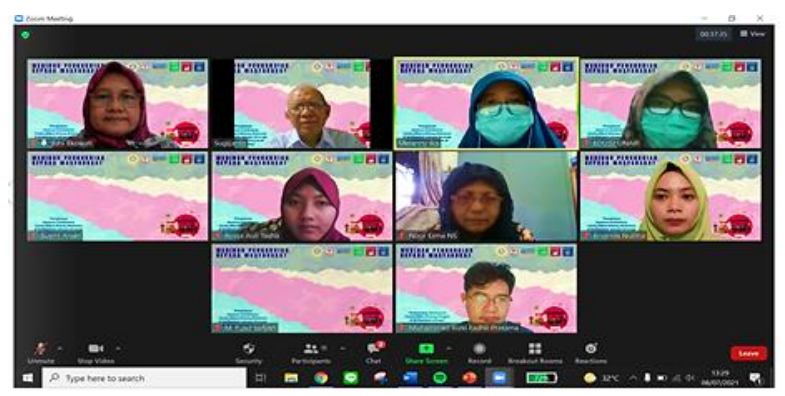

Gambar 1. Tim pengabdian masyarakat Departemen Ilmu Kefarmasian Fakultas Farmasi Universitas Airlangga

\section{METODOLOGI}

\section{Metode edukasi}

Edukasi dilakukan secara daring menggunakan fitur online meeting dari Zoom. Pemaparan materi dilakukan secara konvensional menggunakan metode ceramah dari tiga narasumber. Edukasi disampaikan dalam 3 sesi (Gambar 2) yaitu:

1. Sesi 1. Sesi ini membahas tentang Cara Produksi Pangan yang Baik (CPPB) untuk industri rumah 
tangga. Sesi ini bertujuan untuk memberikan pemahaman kepada peserta terkait aspek penting CPPB dan penerapannya dalam proses produksi pangan. Pada sesi ini, narasumber menyampaikan informasi mengenai:

a. Aspek-aspek $\mathrm{CPPOB}$, yang meliputi: Lokasi dan Lingkungan Produksi; Bangunan dan Fasilitas; Peralatan Produksi; Suplai Air atau Sarana Penyediaan Air; Fasilitas dan Kegiatan Higiene dan Sanitasi; Kesehatan dan Higiene Karyawan; Pemeliharaan dan Program Higiene Sanitasi Karyawan; Penyimpanan; Pengendalian Proses; Pelabelan Pangan; Pengawasan oleh Penanggungjawab; Penarikan Produk; Pencatatan dan Dokumentasi; serta Pelatihan Karyawan.

b. Pemetaan persyaratan CPPOB-IRT dan konsekuensi jika tidak memenuhi persyaratan. Klausul CPPOB-IRT terdiri atas empat tingkatan, yaitu "harus" (shall), "seharusnya" (should), "sebaiknya" (may) dan "dapat" (can), yang diberlakukan terhadap semua lingkup yang terkait dengan proses produksi, pengemasan, penyimpanan dan atau pengangkutan pangan IRT.

2. Sesi 2. Sesi ini membahas tentang BTP yang aman. Sesi ini bertujuan untuk memberikan pemahaman kepada peserta terkait penggunaan BTP yang aman dan sesuai regulasi, khususnya jenis pemanis, pengawet, dan pewarna. Dalam sesi ini, narasumber menyampaikan informasi-informasi terkait:

a. Pengenalan jenis pemanis, pengawet, dan pewarna, dan keamanannya.

b. Pemahaman tentang batas maksimum BTP yang diperbolehkan beserta pelatihan menghitung BTP dalam produk.

c. Pengenalan BTP yang dilarang.
3. Sesi 3. Sesi ini membahas tentang pertimbangan pemilihan kemasan pangan dan tata cara pelabelan produk pangan. Sesi ini bertujuan untuk memberikan pemahaman kepada peserta terkait pertimbangan pemilihan kemasan dan rancangan kemasan yang sesuai dengan regulasi yang ada. Pada sesi ini, narasumber menyampaikan informasi mengenai:

a. Pengenalan karakteristik kemasan yang umum digunakan. Identifikasi kekurangan dan kelebihannya.

b. Hal-hal yang berkaitan dengan keamanan kemasan pangan sesuai regulasi.

c. Kode tara pangan dan kode daur ulang kemasan

d. Informasi yang harus dicantumkan dalam label kemasan pangan.



a

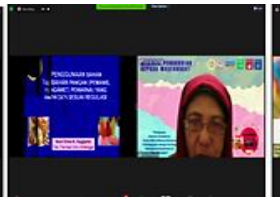

b

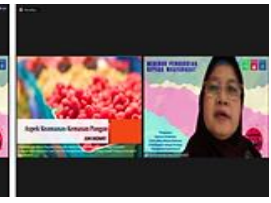

Gambar 2. Materi edukasi pada sesi (a) pertama, (b) kedua, dan (c) ketiga

Diskusi materi dipimpin oleh moderator, dimana peserta mempersiapkan pertanyaan, kemudian narasumber akan menjawab pertanyaan tersebut. Edukasi ini dinyatakan memenuhi syarat keberhasilan jika:

1. $\geq 90 \%$ peserta lulus dalam edukasi, dinyatakan dengan perolehan nilai posttest $>70$

2. terdapat kenaikan tingkat pemahaman peserta yang dapat dinilai dari

a. peningkatan nilai rata-rata

b. peningkatan persentase nilai peserta pada rentang yang lebih tinggi

c. nilai signifikansi ( $p$ value) antara sebelum edukasi (pretest) dan setelah edukasi (posttest).

3. Didapatkan capaian penilaian $>4.5$ pada evaluasi kegiatan 


\section{Metode analisis data}

Data yang akan dianalisis lebih lanjut adalah data dari peserta yang mengerjakan pretest dan posttest secara lengkap. Peserta yang hanya mengerjakan salah satu jenis test saja akan didiskualifikasi dan dikeluarkan dalam data perhitungan. Nilai pretest dan posttest dianalisis menggunakan analisis t-test (paired two samples for means) menggunakan fitur "Data Analysis" pada Microsoft Excel. Pengambilan kesimpulan dilakukan dengan melakukan pengujian terhadap hipotesis sebagai berikut:

$\mathrm{H}_{0}: \mu 1 \leq \mu 2$ (Nilai posttest peserta setelah mengikuti edukasi adalah lebih kecil atau sama dengan nilai pretest peserta sebelum mengikuti edukasi)

$\mathrm{H}_{1}: \mu 1>\mu 2$ (Nilai posttest peserta setelah mengikuti edukasi lebih besar daripada nilai pretest sebelum mengikuti edukasi)

Significance level $(\alpha)=5 \%$ atau 0.05

Kriteria penerimaan Uji Hipotesis :

$\mathrm{H}_{0}$ diterima jika thitung $\leq \mathrm{t}$ tabel atau $\mathrm{p}$-value $>\mathrm{a}$

$\mathrm{H}_{0}$ ditolak jika thitung $>\mathrm{t}$ tabel atau $\mathrm{p}$-value $\leq \mathrm{a}$

Metode pembuatan modul edukasi

Modul edukasi yang akan dibuat adalah modul mengenai kemasan, label, dan informasi nilai gizi pada produk pangan olahan usaha kecil dan usaha mikro. Modul dibuat melalui telaah pustaka dari regulasiregulasi terkait yang diterbitkan pemerintah, antara lain: Peraturan BPOM No 13 Tahun 2016 tentang Pengawasan Klaim pada Label dan Iklan Pangan Olahan, 2016; Peraturan BPOM No 31 Tahun 2018 tentang Label Pangan Olahan, 2018; Peraturan BPOM No 20 Tahun 2019 tentang Kemasan Pangan, 2019; Peraturan BPOM No 22 Tahun 2019 tentang Informasi Nilai Gizi pada Label Pangan Olahan, 2019; Peraturan BPOM Nomor 16 Tahun 2020 tentang Pencantuman Informasi Nilai Gizi, 2020; Permenperin RI No 20 Tahun
2020 tentang Pemberlakuan Standar Nasional Indonesia Kertas dan Karton, 2020.

\section{HASIL DAN PEMBAHASAN}

Edukasi ini diikuti oleh 174 orang peserta, akan tetapi hanya 155 peserta yang memenuhi persyaratan pengerjaan pretest dan posttest secara lengkap. Foto beberapa peserta dan pemateri ditampilkan pada Gambar3. Data 155 peserta inilah yang kemudian diolah lebih lanjut. Soal yang diberikan pada pretest sama dengan soal pada posttest dengan rentang nilai 0-100 poin, soal ini berasal dari materi yang telah dipaparkan oleh narasumber pada masing-masing sesi. Data kemudian digolongkan berdasarkan capaian rentang nilai, rata-rata nilai berdasarkan jenis kelamin, berdasarkan pendidikan, serta berdasarkan rentang usia untuk menilai pengaruh dari masing-masing variabel.

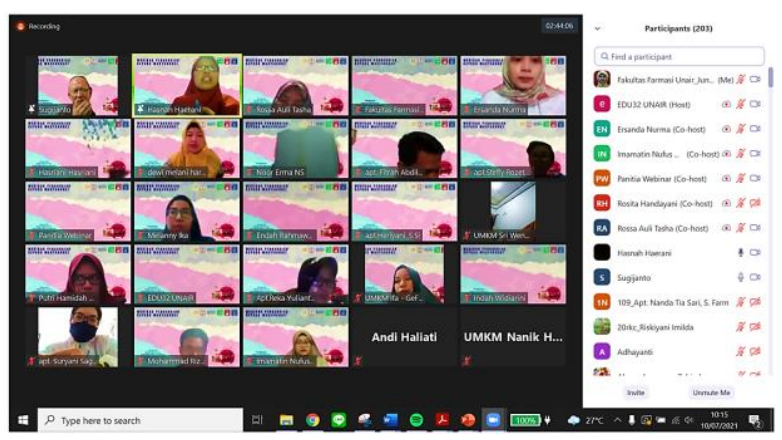

Gambar 3. Foto beberapa peserta kegiatan

Perbandingan nilai pretest dan posttest secara umum ditunjukkan Gambar 4. Berdasarkan data pada Gambar 4 dapat dilihat bahwa terdapat kecenderungan penurunan jumlah peserta yang mendapatkan rentang 61-70 dan 71-80 saat pretest dibandingkan saat posttest. Tampak adanya peningkatan cukup pesat pada rentang nilai 81-90 dan 91-100 pada saat posttest jika dibandingkan dengan kondisi pretest. Persentase peserta dengan rentang nilai 31-40 pada saat pretest sebesar 1\% turun menjadi $0 \%$ pada posttest, rentang nilai $41-50$ pada saat pretest sebesar 3\% turun menjadi 0\% pada saat 
posttest, rentang nilai $51-60$ pada pretest $2 \%$ turun menjadi $1 \%$, rentang nilai $61-70$ pada saat pretest $18 \%$ turun menjadi $6 \%$, rentang nilai $71-80$ saat pretest $35 \%$ turun menjadi $15 \%$, sementara itu untuk rentang nilai $81-90$ dan 91-100 pada saat pretest masing-masing sebesar $28 \%$ dan $14 \%$ naik menjadi masing-masing 35\% dan $42 \%$ pada saat posttest. Ambang batas nilai yang ditetapkan untuk dinyatakan lulus edukasi adalah $>70$, sehingga dari sebaran data diketahui bahwa 92\% peserta telah lulus edukasi dan terget edukasi telah tercapai. Terdapat sebanyak $8 \%$ peserta yang masih memperoleh nilai $\leq 70$. Setelah dianalisis lebih lanjut, peserta ini mengalami gangguan koneksi ketika proses edukasi sedang berlangsung, hal ini menyebabkan proses transfer informasi menjadi terlambat. Faktor lain yang mungkin berperan adalah tingkat pendidikan yang ditunjukkan pada Tabel I.

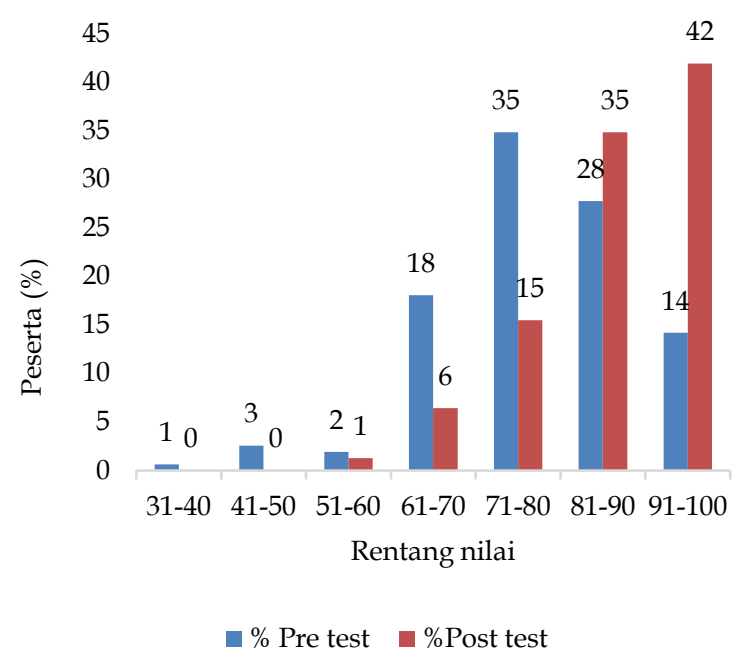

Gambar 4. Perbandingan nilai pretest dan posttest peserta

Tabel I. Rata-rata nilai pretest dan posttest berdasarkan jenjang pendidikan

\begin{tabular}{lccc}
\hline $\begin{array}{c}\text { Jenjang } \\
\text { pendidikan }\end{array}$ & Jumlah & $\begin{array}{c}\text { Rata-rata } \\
\text { nilai pretest }\end{array}$ & $\begin{array}{c}\text { Rata-rata nilai } \\
\text { posttest }\end{array}$ \\
\hline Profesi & 127 & 78.39 & 88.85 \\
S1 & 9 & 70.99 & 87.65 \\
S2 & 5 & 75.56 & 75.56 \\
SMA & 12 & 77.78 & 77.31 \\
SMP & 2 & 55.56 & 77.78 \\
\hline Total peserta & $\mathbf{1 5 5}$ & $\mathbf{7 7 . 5 3}$ & $\mathbf{8 7 . 3 1}$ \\
\hline
\end{tabular}

Peserta webinar ini didominasi oleh perempuan, dengan komposisi jumlah perempuan 139 orang dan laki-laki 16 orang. Rata-rata nilai pretest secara total adalah 77.53 dan posttest adalah 87.31. Peserta perempuan mendapatkan nilai rata-rata lebih tinggi daripada laki-laki berturutturut yaitu 77.66 untuk pretest dan 87.49 untuk posttest (perempuan) dan 76.39 untuk pretest dan 85.76 untuk posttest (laki-laki).

Ditinjau dari tingkat pendidikan, peserta edukasi didominasi oleh mereka yang lulus pada jenjang profesi yaitu sebanyak 127 orang. Jika dilihat dari Tabel I dan Gambar 5, tampak bahwa pendidikan cukup berpengaruh secara signifikan terutama pada hasil pre test. Hasil pretest maupun posttest pada jenjang Profesi lebih tinggi jika dibandingkan dengan jenjang S1, SMA, dan SMP. Tampak adanya anomali bahwa hasil pretest peserta pada jenjang SMA, niai rata-rata pada pretest lebih tinggi daripada S1 maupun S2. Hasil telaah menunjukkan adanya faktor lain yang mempengaruhi yaitu pengalaman dalam dunia usaha dan terjun langsung dalam pengelolaan usaha tersebut.

Rata-rata nilai pretest $\quad$ Rata-rata nilai posttest

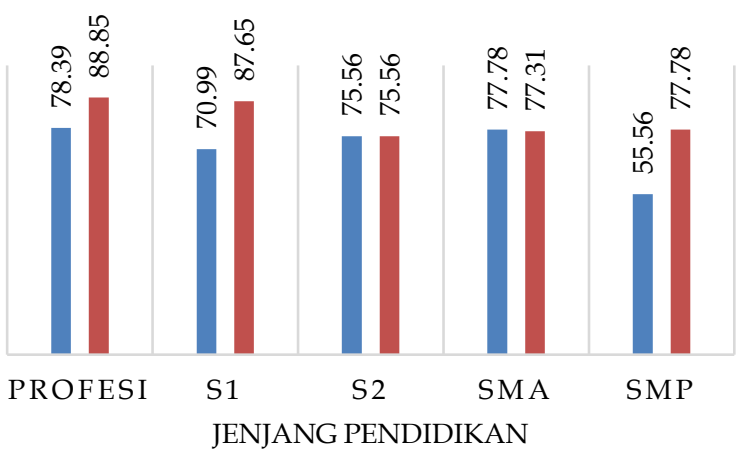

Gambar 5. Perbandingan nilai pretest dan posttest peserta berdasarkan jenjang pendidikan

Ditinjau dari perbedaan usia, didapatkan hasil bahwa faktor usia tidak berpengaruh terhadap nilai pretest dan posttest (Tabel II dan Gambar 6) dalam edukasi ini. Di 
tengah kemajuan teknologi dan IT, usia lebih muda diidentikkan dengan kemampuan menyerap informasi lebih baik daripada orang tua, namun hal ini mulai banyak dikritisi karena kemampuan menyerap informasi juga dipengaruhi oleh pengalaman dan efisiensi dalam membaca. Efisiensi membaca dinilai sebagai waktu yang dihabiskan untuk membaca dibagi dengan jumlah diingat untuk setiap bagian. Hasil menunjukkan bahwa efisiensi membaca meningkat dengan meningkatnya tingkat pengetahuan di kalangan orang dewasa yang lebih tua tetapi tidak lebih muda (Miller, 2009). Faktor pengalaman para peserta menjalankan usaha memiliki durasi yang berbeda sehingga memunculkan perbedaan dalam tingkat pemahaman terhadap informasi, terutama terkait regulasi yang berlaku.

Tabel II. Rata-rata nilai pretest dan posttest berdasarkan rentang usia

\begin{tabular}{lccc}
\hline $\begin{array}{c}\text { Rentang } \\
\text { usia (tahun) }\end{array}$ & $\begin{array}{c}\text { Jumlah } \\
\text { peserta }\end{array}$ & $\begin{array}{c}\text { Rata-rata } \\
\text { nilai pretest }\end{array}$ & $\begin{array}{c}\text { Rata-rata } \\
\text { nilai posttest }\end{array}$ \\
\hline $18-30$ & 59 & 79.47 & 89.92 \\
$30-40$ & 60 & 76.02 & 86.11 \\
$40-50$ & 26 & 75.85 & 83.12 \\
$50-60$ & 10 & 79.44 & 90.00 \\
\hline Total & $\mathbf{1 5 5}$ & $\mathbf{7 7 . 5 3}$ & $\mathbf{8 7 . 3 1}$ \\
\hline
\end{tabular}

— Rata-rata nilai pretest $\quad$ Rata-rata nilai posttest

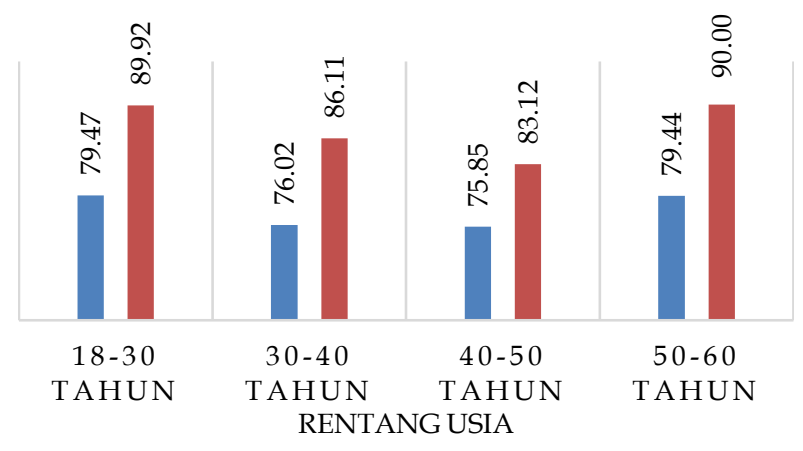

Gambar 6. Perbandingan nilai pretest dan posttest peserta berdasarkan usia

Analisis t-test (paired two samples for means) menggunakan fitur data analysis pada Microsoft Excel/dilakukan untuk menilai keberhasilan edukasi yang dilakukan, berupa peningkatan pemahaman peserta terkait bahan tambahan pangan, label, dan kemasan pangan. Dari analisis tersebut, didapatkan hasil thitung ( $\mathrm{tStat}$ ) $>\mathrm{t}$ tabel (t Critical), nilai $\mathrm{p}$ value $<\mathrm{a}$ (Tabel III), sehingga $\mathrm{H}_{0}$ ditolak, dan $\mathrm{H}_{1}$ diterima. Artinya ada perbedaan antara nilai pretest dan posttest dimana nilai posttest secara ratarata lebih tinggi daripada nilai pretest. Dari data ini dapat disimpulkan bahwa secara statistik edukasi yang dilakukan terbukti dapat meningkatkan pemahaman peserta.

Tabel III. Hasil analisis statistik dengan t-test: paired two samples for means

\begin{tabular}{lcc}
\hline & Posttest & Pretest \\
\hline Mean & 87.31 & 77.53 \\
Variance & 118.15 & 144.44 \\
Observations & 155 & 155 \\
Pearson Correlation & 0.474 & \\
Hypothesized Mean Difference & 0 & \\
df & 154 & \\
t Stat & 10.34 & \\
P(T<=t) one-tail & 0.00 & \\
t Critical one-tail & 1.65 & \\
\hline
\end{tabular}

Analisis pemahaman pada tiap soal pretest dan posttest dilakukan pada kegiatan ini untuk memetakan konten edukasi yang masih harus diperbaiki baik dalam metode penyampaian maupun teknik pengemasan materi. Hasil analisis tiap soal disajikan pada Tabel IV. Soal terbagi tiga tipe, yaitu soal untuk menilai pemahaman tentang aspek CPPOB, soal untuk menilai pemahaman tentang aspek BTP, dan soal untuk menilai pemahaman tentang pemilihan kemasan dan keamanannya. Dari Tabel IV dapat diambil kesimpulan bahwa peserta secara umum sudah mampu memahami materi terkait pemilihan kemasan, namun dalam hal istilah keamanan kemasan, keamanan penggunaan BTP dan teknis pelabelan dalam kaitannya dengan perizinan PIRT, capaian pemahaman peserta masih dibawah $70 \%$. Berdasarkan data capaian pemahaman peserta tersebut, maka untuk diharapkan peserta yang mengikuti kegiatan edukasi ini dapat membagi ilmunya kepada pelaku UMKM lainnya yang belum berkesempatan mengikuti kegiatan ini. 
Tabel IV. Data analisis capaian per soal

\begin{tabular}{|c|c|}
\hline Materi Pertanyaan & $\begin{array}{c}\text { \% Jumlah } \\
\text { peserta yang } \\
\text { menjawab } \\
\text { benar }\end{array}$ \\
\hline $\begin{array}{l}\text { Bahan yang tidak boleh digunakan sebagai } \\
\text { bahan pengawet makanan }\end{array}$ & 96.77 \\
\hline $\begin{array}{l}\text { Kondisi yang tidak diperkenankan pada } \\
\text { kemasan PET }\end{array}$ & 95.48 \\
\hline $\begin{array}{l}\text { Informasi yang TIDAK } \\
\text { dicantumkan dalam kemasan }\end{array}$ & 94.84 \\
\hline $\begin{array}{l}\text { Informasi Nilai Gizi wajib dicantumkan } \\
\text { dalam kemasan produk pangan olahan } \\
\text { yang ingin diajukan nomor registrasinya ke } \\
\text { BPOM }\end{array}$ & 94.19 \\
\hline $\begin{array}{l}\text { Bahan pewarna pangan yang boleh } \\
\text { digunakan }\end{array}$ & 92.26 \\
\hline $\begin{array}{l}\text { BTM yang tidak boleh ada pada Roti dan } \\
\text { permen untuk anak-anak }\end{array}$ & 90.97 \\
\hline $\begin{array}{l}\text { Jenis kemasan yang berinteraksi/paling } \\
\text { besar kontaknya dengan pangan }\end{array}$ & 90.97 \\
\hline Pangan yang dimaksud aman & 90.32 \\
\hline $\begin{array}{l}\text { Keterangan kedaluwarsa yang } \\
\text { dicantumkan pada produk pangan Olahan } \\
\text { yang memiliki masa simpan kurang dari } 3 \\
\text { (tiga) bulan }\end{array}$ & 85.16 \\
\hline $\begin{array}{l}\text { Informasi berikut yang seharusnya } \\
\text { dicantumkan dalam kemasan jika dalam } \\
\text { suatu produk digunakan pemanis buatan } \\
\text { sakarin }\end{array}$ & 84.52 \\
\hline $\begin{array}{l}\text { Hal-hal yang perlu disiapkan pengusaha } \\
\text { UMKM untuk proses halal }\end{array}$ & 78.71 \\
\hline Simbol Logo tara pangan & 74.84 \\
\hline $\begin{array}{l}\text { Bahan berbahaya yang terkandung pada } \\
\text { makanan yang menunjukkan adanya } \\
\text { bintik-bintik putih }\end{array}$ & 63.87 \\
\hline Pernyataan tentang SPP-IRT & 61.29 \\
\hline $\begin{array}{l}\text { Bahan tambahan pangan yang } \\
\text { diperbolehkan dalam makanan }\end{array}$ & 60.00 \\
\hline $\begin{array}{l}\text { Jenis pangan yang TIDAK diijinkan untuk } \\
\text { memperoleh SPP-IRT }\end{array}$ & 58.06 \\
\hline $\begin{array}{l}\text { Tanda khusus pewarna makanan yang } \\
\text { harus dicantumkan di etiket wadahnya }\end{array}$ & 52.26 \\
\hline $\begin{array}{l}\text { Perpindahan materi dari kemasan pangan } \\
\text { ke dalam bahan pangan yang dikemas }\end{array}$ & 50.32 \\
\hline
\end{tabular}

Evaluasi terhadap kegiatan juga dilakukan melalui pengisian kuesioner evaluasi kepada peserta dengan indikator yang dicantumkan pada Tabel V. Dari hasil evaluasi kuantitatif didapatkan capaian rata-rata indikator sudah di atas target yang telah ditetapkan yaitu 4.66 (target keberhasilan adalah 4.5). Disamping penilaian kuantitatif, kami juga melakukan penilaian secara kualitatif dengan 5 masukan terbanyak yaitu:

1. Saran agar kegiatan edukasi dibuat berseri dengan topik yang masih berhubungan, misalnya tata cara registrasi produk pangan olahan ke BPOM

2. Saran agar mengajak kerjasama pengurus IAI kota lain

3. Saran agar sesi tanya jawab dibuat lebih panjang sehingga lebih interaktif

4. Saran agar peserta mendapatkan modul materi yang disampaikan

5. Saran agar sosialisasi kegiatan diperluas.

Tabel V. Capaian indikator evaluasi kegiatan

\begin{tabular}{|c|c|c|}
\hline Indikator & Kriteria nilai & Nilai \\
\hline $\begin{array}{l}\text { Sosialisasi kegiatan } \\
\text { (poster, redaksional } \\
\text { pesan berantai) }\end{array}$ & $\begin{array}{l}\text { 1-5 (Tidak jelas-Sangat } \\
\text { Jelas) }\end{array}$ & 4.5 \\
\hline $\begin{array}{l}\text { Sistem pendaftaran } \\
\text { peserta }\end{array}$ & $\begin{array}{l}\text { 1-5 (Sangat menyulitkan- } \\
\text { Sangat mudah) }\end{array}$ & 4.7 \\
\hline Pemaparan materi & $\begin{array}{l}\text { 1-5 (Tidak menarik-Sangat } \\
\text { menarik) }\end{array}$ & 4.7 \\
\hline Acara diskusi & $\begin{array}{l}\text { 1-5 (Tidak memuaskan- } \\
\text { Sangat memuaskan) }\end{array}$ & 4.6 \\
\hline $\begin{array}{l}\text { Topik/informasi } \\
\text { yang dibahas }\end{array}$ & $\begin{array}{l}\text { 1-5 (Tidak menjawab } \\
\text { masalah peserta-Sangat } \\
\text { menjawab masalah } \\
\text { peserta) }\end{array}$ & 4.7 \\
\hline $\begin{array}{l}\text { Kesesuaian judul } \\
\text { program dengan } \\
\text { materi yang } \\
\text { disampaikan }\end{array}$ & $\begin{array}{l}\text { 1-5 (Tidak sesuai-Sangat } \\
\text { sesuai) }\end{array}$ & 4.7 \\
\hline $\begin{array}{l}\text { Tanggapan Anda } \\
\text { atas materi yang } \\
\text { disampaikan }\end{array}$ & $\begin{array}{l}1-5 \text { (Tidak penting-Sangat } \\
\text { penting) }\end{array}$ & 4.7 \\
\hline \multicolumn{2}{|c|}{ Capaian rata-rata } & 4.66 \\
\hline
\end{tabular}

Sebagai tindak lanjut salah satu saran yang disampaikan, disusun sebuah modul terkait kemasan, label, dan informasi nilai gizi pada produk pangan olahan yang diproduksi oleh industri kecil dan mikro. Modul ini dapat diakses pada laman: https://bit.ly/modulpengmasrh; berisi informasi terkait pertimbangan pemilihan dan jenis kemasan, teknis pelabelan kemasan sesuai regulasi, serta tata cara membuat tabel informasi nilai gizi yang disampaikan dengan bahasa yang sederhana dan full color. Peserta diharapkan dapat menyerap informasi dengan lebih maksimal dengan adanya modul tersebut. Kami juga telah melakukan survei untuk penilaian modul dengan hasil ditunjukkan pada Gambar 7. 


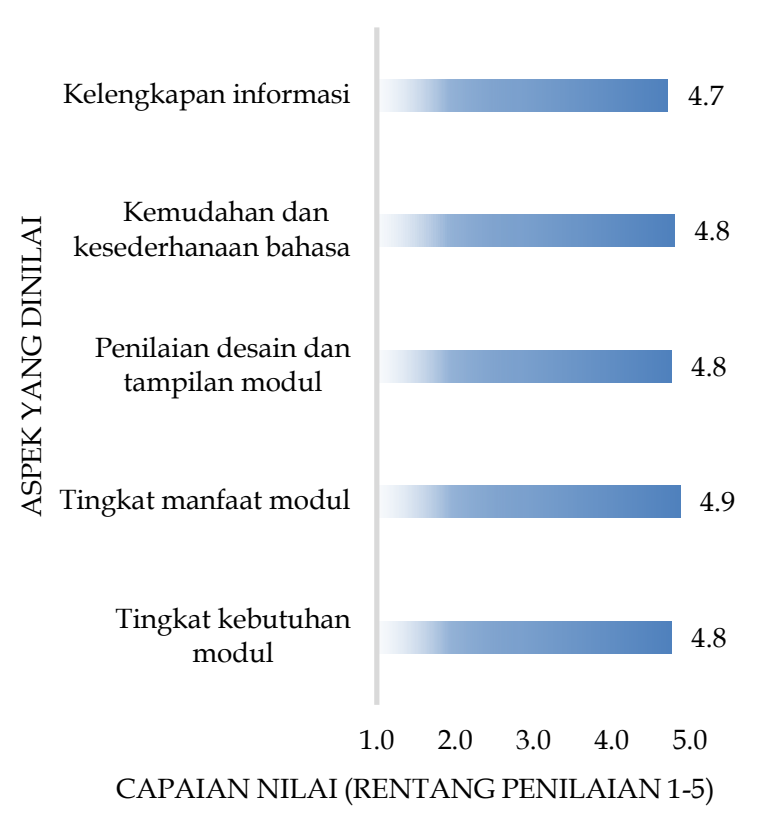

Gambar 7. Capaian penilaian kualitas modul edukasi oleh peserta

Dari serangkaian kegiatan yang dilakukan, tampak bahwa peserta sangat mendukung dan memberi respon positif terhadap kegiatan edukasi yang dilakukan. Adanya perbedaan tingkat pendidikan dan usia bukan menjadi faktor penghalang kegiatan sehingga kegiatan serupa dapat dijalankan pada sebaran pelaku usaha yang lebih luas. Beberapa langkah kegiatan yang dapat dilakukan berikutnya antara lain:

1. Membuat modul yang lebih bervariasi dan dapat diakses masyarakat pelaku usaha pangan olahan lainnya.

2. Melibatkan stakeholder terkait yang saling terhubung dalam mendukung pelaku usaha

\section{KESIMPULAN}

Edukasi yang dilakukan terkait cara pengolahan produk pangan yang baik, penggunaan bahan pangan, dan pemilihan kemasan pangan yang dilakukan oleh tim pengabdian masyarakat Departemen Ilmu Kefarmasian Fakultas Farmasi Universitas Airlangga kepada para pelaku UMKM di Balikpapan terbukti meningkatkan pemahaman para pelaku usaha dan mampu memenuhi target indikator evaluasi kegiatan yang telah ditentukan.

\section{UCAPAN TERIMA KASIH}

Penulis mengucapkan terimakasih kepada Fakultas Farmasi Universitas Airlangga yang telah mendanai Pelaksanaan kegiatan pengabdian kepada masyarakat berikut.

\section{REFERENSI}

Alamri, M.S. Qasem, A.A.A., Mohamed, A.A., Hussain, S., Ibraheem, M.A., Shamlan, G., Alqah, H.A., Qasha, A.S. 2021. Food packaging's materials: A food safety perspective. Saudi Journal of Biological Sciences. 28(8):4490-4499. https:/ / doi.org/10.1016/j.sjbs.2021.04.047

Badan Pengawas Obat dan Makanan Republik Indonesia. 2016. Peraturan BPOM nomor 13 tahun 2016 Tentang Pengawasan Klaim Pada Label Dan Iklan Pangan Olahan. Jakarta: Badan Pengawas Obat dan Makanan Republik Indonesia.

Badan Pengawas Obat dan Makanan Republik Indonesia. 2018. Peraturan BPOM nomor 31 tahun 2018 tentang Label Pangan Olahan. Jakarta: Badan Pengawas Obat dan Makanan Republik Indonesia.

Badan Pengawas Obat dan Makanan Republik Indonesia. 2019a. Laporan Tahunan Badan Pengawas Obat dan Makanan tahun 2019. Jakarta: Badan Pengawas Obat dan Makanan Republik Indonesia.

Badan Pengawas Obat dan Makanan Republik Indonesia. 2019b. Peraturan BPOM nomor 11 tahun 2019 tentang Bahan Tambahan Pangan. Jakarta: Badan Pengawas Obat dan Makanan Republik Indonesia.

Badan Pengawas Obat dan Makanan Republik Indonesia. 2019c. Peraturan BPOM nomor 20 tahun 2019 tentang Kemasan Pangan. Jakarta: Badan Pengawas Obat dan Makanan Republik Indonesia.

Badan Pengawas Obat dan Makanan Republik Indonesia. 2019d. Peraturan BPOM nomor 22 
tahun 2019 tentang Informasi Nilai Gizi Pada Label Pangan Olahan. Jakarta: Badan Pengawas Obat dan Makanan Republik Indonesia.

Badan Pengawas Obat dan Makanan Republik Indonesia. 2020. Peraturan BPOM nomor 16 tahun 2020 tentang Pencantuman Informasi Nilai Gizi. Jakarta: Badan Pengawas Obat dan Makanan Republik Indonesia.

Chaldakov, G.N., Yanev, S., Georgiev, V. 2013. Toxicology of Adipose Tissue (Adipotoxicology), or Adipose Tissue as a “Toxicrine" Organ BT. In Pierce, G. N., Mizin, V.I., Omelchenko, A. (Eds). Advanced Bioactive Compounds Countering the Effects of Radiological, Chemical and Biological Agents. Dordrecht: Springer. pp. 253-260.

Curhan, G.C., Forman, J.P. 2010. Sugar-sweetened beverages and chronic disease. Kidney International. 77(7):569-570. https://doi.org/10.1038/ki.2009.543

Daher, M.I., Matta, J.M., Abdel Nour, A.M. 2019. Nonnutritive sweeteners and type 2 diabetes: Should we ring the bell? Diabetes Research and Clinical $\quad$ Practice. 155:107786. https://doi.org/10.1016/j.diabres.2019.10778 6

Miller, L.M.S. 2009. Age Differences in the Effects of Domain Knowledge on Reading Efficiency. Psychology and Aging. 24(1):63-74. https://doi.org/10.1037/a0014586

Perdana, W.Y., Jacobus, D.J. 2016. Bisphenol A (BPA) adalah Endocrine Disrupture Chemicals (EDC) yang Berperan sebagai Agen Diabetogenikitle. CDK (Cermin Dunia Kedokteran). 43(9):706-711.

Kementerian Perindustrian Republik Indonesia. 2020. Peraturan Menteri Perindustrian Republik Indonesia nomor 20 tahun 2020 tentang Pemberlakuan Standar Nasional Indonesia Kertas dan Karton. Jakarta: Kementerian Perindustrian Republik Indonesia.

Piringer, O.G., Baner, A.L. 2008. Plastic Packaging: Interaction with Food and Pharmaceuticals. Weinheim, Wiley-VCH. https://doi.org/10.1002/9783527621422

Trasande, L., Shaffer, R.M., Sathyanarayana, S. 2018. Food additives and child health. Pediatrics. 142(2):e20181408.

https://doi.org/10.1542/peds.2018-1408 